\title{
CHEMICAL CONTROL
}

\section{Chemical control of white grub Liogenys fuscus (Blanchard 1851) (Coleoptera: Melolonthidae) in cornfields}

\author{
Antônio C. SAntos ${ }^{1}$, Adeney F. Bueno ${ }^{2}$, Regiane C. O. F. Bueno ${ }^{3}$ E Simone S. Vieira ${ }^{4}$ \\ ${ }^{1}$ Dow AgroSciences Industrial Ltda, São Paulo, SP. E-mail: acsantos1@dow.com \\ ${ }^{2}$ Current address: Embrapa Soja, Londrina, PR. E-mail: adeney@cnpso.embrapa.br \\ ${ }^{3}$ Escola Superior de Agricultura “Luiz de Queiroz”-ESALQ/USP, Piracicaba, SP. E-mail: rcdolive@esalq.usp.br \\ ${ }^{4}$ Centro Federal de Ensino Tecnológico, CEFET, Rio Verde, GO.
}

BioAssay 3:5 (2008)

Controle químico do coró Liogenys fuscus (Blanchard 1851) (Coleoptera: Melolonthidae) na cultura do milho

\begin{abstract}
RESUMO - Pragas de solo como o complexo de corós são de grande importância nas culturas de milho e soja em várias regiões produtoras do Brasil, sendo que Liogenys fuscus (Blanchard) é a espécie mais comum na região CentroOeste. Os produtores de milho têm utilizado inseticidas para controle dessas pragas iniciais; entretanto, pouco se conhece sobre a eficiência dos diferentes inseticidas no controle de L. fuscus. Sendo assim, o objetivo do presente trabalho foi avaliar a eficiência de alguns inseticidas, aplicados no solo no sulco de plantio ou em tratamento de sementes, para o manejo de L. fuscus na cultura do milho no Estado de Goiás, durante as safras de 2004/2005 e 2005/2006. Durante a safra 2004/2005, os tratamentos testados foram clorpirifós 450, 675, 900 e 1170 g.ha ${ }^{-1}$, endosulfan 525 g.ha ${ }^{-1}$, fipronil 160 g.ha ${ }^{-1}$ aplicados no sulco de plantio e durante a safra 2005/2006 os tratamentos foram clorpirifós 450 e 675 g.ha ${ }^{-1}$, fipronil 160 g.ha $^{-1}$ aplicados no sulco de plantio e também fipronil 37,5 e 50 g.100 $\mathrm{kg}$ de sementes ${ }^{-1}$ e tiametoxam $70 \mathrm{~g} .100 \mathrm{~kg}$ sementes $^{-1}$ em tratamento de sementes. Os resultados mostraram que: clorpirifós $\left(450,0\right.$ g.ha $\left.{ }^{-1}\right)$ pulverizado no sulco de plantio foi suficiente para o controle de L. fuscus, observando-se um estande de até sete vezes maior e um tamanho de planta de aproximadamente duas vezes maior em relação ao tratamento testemunha na safra 2004/2005 devido ao ataque da praga. Resultados semelhantes foram obtidos com fipronil (160,0 g.ha $\left.{ }^{-1}\right)$ também aplicado no sulco de plantio sendo que ambos foram superiores ao endosulfam na dose de 525,0 g.ha ${ }^{-1}$ nesta safra. Já na safra 2005/2006 não se observou incremento ao tamanho de planta e estande devido à aplicação dos inseticidas, sendo que as plantas não apresentaram sintomas de ataque da praga. Nessa safra os resultados apresentados pelos tratamentos de sementes (fipronil 37,5 e $50 \mathrm{~g} .100 \mathrm{~kg}$ de sementes ${ }^{-1}$ e tiametoxam 70 g. $100 \mathrm{~kg}$ de sementes ${ }^{-1}$ ) também foram similares ao clorpirifós e fipronil na aplicação realizada no sulco de plantio, podendo, portanto ser considerada uma outra opção de controle químico para o manejo dessa praga. Sendo assim clorpirifós e fipronil aplicados no sulco de plantio além de fipronil e tiametoxam aplicados em tratamento de semente podem ser alternativas de controle químico de L. fuscus na cultura de milho em condições semelhantes ao encontrado nesses experimentos.
\end{abstract}

PALAVRAS-CHAVE - Zea mays L., clorpirifós, endosulfam, fipronil, tiametoxam, pragas de solo.

ABSTRACT - Soil pests such as the white grub complex are of great importance in different Brazilian regions, and Liogenys fuscus (Blanchard) is the most common species at the Brazilian Western Central Region. Corn producers had largely relied on pesticides to keep initial pest outbreaks under control, however, there is little information regarding the efficacy of different insecticides to control L. fuscus. The objective of this research was to evaluate the effectiveness of some insecticides, applied either to the soil or the seed, in controlling L. fuscus in cornfields in State of Goiás during two crop seasons. In 2004/2005 season the following chemicals were applied in furrow: chlorpyrifos (450, 675, 900, and 1170 g.ha $\left.{ }^{-1}\right)$; endosulfan $\left(525\right.$ g.ha $\left.^{-1}\right)$; and fipronil $\left(160\right.$ g.ha $\left.^{-1}\right)$. During the 2005/2006 season the treatments were chlorpyrifos $\left(450\right.$ and $\left.675 \mathrm{~g} \mathrm{ha}^{-1}\right)$, fipronil $\left(160 \mathrm{~g} \cdot \mathrm{ha}^{-1}\right)$, both applied in furrow, as well as fipronil (37.5 and $50 \mathrm{~g} .100 \mathrm{~kg}$ of seeds $\left.{ }^{-1}\right)$ and thiamethoxan $\left(70 \mathrm{~g} .100 \mathrm{~kg}\right.$ of seeds $\left.{ }^{-1}\right)$ applied as seed treatment. The results showed that chlorpyrifos (450.0 g.ha $\left.{ }^{-1}\right)$ in furrow was effective to control L. fuscus. Plant stand and plant size in this treatment were 7-fold and 2-fold taller than plants in the control plots, during the 2004/2005 season. Similarly, fipronil 160.0 g.ha ${ }^{-1}$ applied in furrow had positive results, both outperforming endosulfan $525.0 \mathrm{~g} . \mathrm{ha}^{-1}$ in furrow application. However, during the 2005/2006 season there was no benefit regarding plant stand or plant size due to insecticide 
application, and no pest injury was observed in the plants. During this crop season, results recorded for the seed treatment (fipronil 37.5 and $50 \mathrm{~g} .100 \mathrm{~kg}$ of seeds ${ }^{-1}$ and thiamethoxan $70 \mathrm{~g} .100 \mathrm{~kg}$ of seeds ${ }^{-1}$ ) were also similar to the chlorpyrifos and fipronil in furrow treatment, which may be considered to be used as a chemical control procedure. Therefore, under conditions similar to those prevalent during the execution of these trials, in furrow application of chlorpyrifos and fipronil as well as seed treatment with fipronil and thiamethoxan may be used to control L. fuscus outbreaks in cornfields.

KEYWORDS - Zea mays L., chlorpyrifos, endosulfan, fipronil, thiamethoxam, soil pests.

The occurrence of soil pests has been increasingly important to grain producers in Brazil. Among them, there are several species of white grubs (Cruz et al. 1999) that can be devastating agricultural pests by feeding on crop roots often causing plant death or severe injury and impairing full harvest potential. These pests used to be of secondary importance, however the adoption of no-tillage crop management with an intensive use of chemicals has favored their occurrence and serious outbreaks have occurred, mostly in corn and soybean fields (Grassen 1993, Viana et al. 2001). Moreover, larval infestations are greatly influenced by soil type or texture (Morón 2004) and fibrous-rooted plants, such as corn, are susceptible whereas stronger tap-rooted plants are often more tolerant to injury.

There are several white grub species of economic importance in Brazil (Oliveira et al. 2004). Phyllophaga cuyabana (Moser) has been commonly reported damaging different crops roots in Brazil (Oliveira et al. 1992, Oliveira 1997). In the State of Rio Grande do Sul, Phyllophaga triticophaga (Morón \& Salvadori) and Diloboderus abderus (Sturm) have damaged not only corn but also soybeans and wheat (Silva 1995, Salvadori 2000). In Goiás, species commonly associated with crop roots have been Liogenys fuscus (Blanchard) (Coleoptera: Melolonthidae), damaging soybeans, corn, and sorghum (Costa et al. 2004). L. fuscus outbreaks clearly affected soybean and corn production in Goiás in 2002 and 2003 mainly at Edéia and Leopoldo de Bulhões towns. Economic losses however were not precisely quantified. As well as other pests, such as the stink bugs, white grub outbreaks might also be more severe for maize sown off-season since the population increases and the insects develop during the season (Waquil et al. 2004). Fields planted earlier (September, October) are less damaged by white grubs than late sown fields (December) (Oliveira et al. 2004).

There are different ways of suppressing soil pest populations using chemical and biological techniques (Pedigo 2002). However, there is not sufficient information regarding the efficacy of chemical control of white grubs, mainly because these pests used to be of secondary importance and also because research works addressing their control usually require intensive labor and are difficult to be carried out. Also, information about insecticide efficacy over these pests is insufficient, especially regarding L. fuscus which presents higher incidence in the Western Central Region.

Growers usually rely on chemical control only, but they also have been testing different insecticides at different rates and methods, but due to the lack of standardized methodology very few results were obtained so far. Therefore, information regarding these aspects is crucial to provide efficient control of L. fuscus outbreaks. This research was carried out to evaluate some insecticides applied in furrow and as seed treatment in order to control L. fuscus population in corn fields.

\section{Material and Methods}

Two field trials were conducted in corn fields located in Edéia, GO, Brazil from 2004 to 2006. The insecticides tested were chlorpyrifos, endosulfan, fipronil and thiamethoxan. The experiments were carried out in conventional corn crop management. Infestation was observed during an evaluation done the day before insecticide application. The experimental design was a Randomized Complete Block (RCB) with 4 replications.

The first experiment was sowed in December, 2004 with the folllowing threatments: (1) chlorpyrifos 450 g.ha ${ }^{-1}$ (Sabre ${ }^{\circledR} 450 \mathrm{EW}$, Dow AgroSciences Industrial Ltda); (2) chlorpyrifos 675 g.ha ${ }^{-1}$ (Sabre ${ }^{\circledR} 450$ EW, Dow AgroSciences Industrial Ltda); (3) chlorpyrifos 900 g.ha ${ }^{-}$ ${ }^{1}$ (Sabre ${ }^{\circledR} 450 \mathrm{EW}$; Dow AgroSciences Industrial Ltda); (4) chlorpyrifos 1170 g.ha- ${ }^{-1}\left(\right.$ Sabre $^{\circledR} 450$ EW, Dow AgroSciences Industrial Ltda); (5) endosulfan 525 g.ha $^{-1}$ (Thiodan $^{\circledR} 350$ CE, Bayer CropSciences Ltda); (6) fipronil 160 g.ha- ${ }^{-1}$ (Regente ${ }^{\circledR}$ 800WG, Basf S.A.); 7. Control (water). All treatments were applied in furrow above the seed using a backpack $\mathrm{CO}_{2}$ sprayer with constant pressure. The equipment was set to deliver 50 L.ha ${ }^{-1}$ similarly to the usual procedure practiced by farmers. The second experiment was sowed at October/2005 with the following treatments: (1) chlorpyrifos 450 g.ha ${ }^{-1} \quad\left(\right.$ Sabre $^{\circledR} 450$ EW, Dow AgroSciences Industrial Ltda); (2) chlorpyrifos 675 g.ha ${ }^{-}$ ${ }^{1}$ (Sabre ${ }^{\circledR} 450 \mathrm{EW}$, Dow AgroSciences Industrial Ltda); (3) friponil 160 g.ha-1 ${ }^{-1}$ Regente ${ }^{\circledR} 800 \mathrm{WG}$, Basf S.A.); (4) fipronil $37.5 \mathrm{~g} .100 \mathrm{~kg}$ of seeds ${ }^{-1}\left(\right.$ Standak $^{\circledR} 250 \mathrm{EC}$, Basf S.A.); (5) fipronil 50.0 g.100 kg of seeds $^{-1}$ (Standak $^{\circledR}$ 
250 EC, Basf S.A.); (6) thiamethoxan 70.0 g.100 kg of seeds $^{-1}$ (Cruiser $^{\circledR}$ 700WS, Syngenta Proteção de Cultivos Ltda); (7) Control (water). Furrow application was performed as described for the first experiment. Seed treatment was accomplished applying the insecticides inside a plastic bag and using $500 \mathrm{ml}$ of mixture. $100 \mathrm{~kg}$ of seeds ${ }^{-1}$. In all trials, seeds were sowed by hand, providing good precision regarding the number of seeds used per plot ( 5 seeds/meter).

Trials were evaluated at 45 and 26 days after sowing for the first (2004/2005 season) and second trial (2005/2006 season), respectively. Each evaluation was done in a hole $20 \mathrm{~cm}$ deep by $20 \mathrm{~cm}$ wide, dug along one meter of the central planting row of each plot $(1.00 \mathrm{x}$ $0.20 \times 0.20 \mathrm{~m}$ ), and carefully searching the removed soil to detect the presence and count $L$. fuscus larvae. Before sowing, pre-scouting was randomly done at 10 points selected inside field trial areas. In addition to white grub counting, the number of plants and size of 20 plants/plot were recorded to evaluate plant injury caused by insect feeding. Data were subjected to ANOVA and treatment means were separated by Tukey test $(\alpha=5 \%)$.

\section{Results and Discussion}

In the first trial, pre-counting samples inside plots found $30 \pm 4$ nymphs of L. fuscus.meter ${ }^{-1}\left(0.04 \mathrm{~m}^{3}\right.$ of soil). Because trial was installed late in season (late December, 2004), the majority of these nymphs were of $3^{\text {rd }}$ instar. Nymphs at this stage as well as at later instars have greater damage potential (Oliveira et al. 2004) and might have caused the observed significant reduction in plant stand on control plots (98\% of reduction) (Figure 1B).

The fact that white grubs are active in the soil looking for food, may explain the presence of very few white grubs in the control plots at 45 days after sowing. Control plots presented very few corn plants (Figure 1B) with injured root systems that caused reduced plant size (Figure 1C). Consequently, due to the lack of food in the control plots, white grubs nymphs present in these areas might have migrated to the surrounding plots. Control plots with higher pest infestation than treated plots were also reported by Ceccon et al. (2004), suggesting that the evaluation should be conducted previously. Considering that best time for evaluation is still unknown, it might be necessary to test several periods after sowing in future experiments.

Due to the lack of white grubs in the control plot at 45 days after planting, ANOVA was run only for the insecticide treatments to separate treatment effects. Results showed that chlorpyrifos (all tested rates) and fipronil $\left(160 \mathrm{~g}\right.$.ha $\left.{ }^{-1}\right)$ were the best treatments outperforming endosulfan (525 g.ha $\left.{ }^{-1}\right)$ in furrow application (Figure 1A). Recording plant number and measuring plants height might also be helpful to evaluate control efficacy. Taking the number and size of plants into consideration, all insecticide treatments differed from control but did not differ among themselves. Endosulfan (525 g.ha ${ }^{-1}$ ) was numerically the worst treatment in both plant stand (Figure 1B) and plant size (Figure 1C). Therefore, endosulfan was in general the worst in furrow treatment showing the highest number of white grubs (Figure 1A) and numerically the lowest plant stand and plant size among all insecticides tested (Figures 1B and 1C).

According to Mayo (1986), insecticide efficacy trials for soil pests usually separate excellent controlling insecticides from low control ones. However, it is not an easy task to separate insecticides with intermediate control levels which might be the case for endosulfan on this experiment.

In the second trial (2005/2006 season), precounting samples inside plots found $20 \pm 2$ nymphs of $L$. fuscus.meter ${ }^{-1}\left(0.04 \mathrm{~m}^{3}\right.$ of soil). Because trial was installed early in season (early October, 2005), the majority of these nymphs were of $1^{\text {st }}$ or $2^{\text {nd }}$ instar. Nymphs from early instars are sometimes not damaging to plants that tolerate some root injury. Usually when crops are sowed early in the season (September, October), white grubs do not cause as much damage as it is seen on crops sowed late in the season (December) (Oliveira et al. 2004).

This is a possible explanation why insecticide treatments did not statistically differ from control for both plant stand (Figure 2B) and plant size (Figure 2C). Other factors might also explain differences found in both trials. There are other important factors that interfere on insect outbreaks such as soil humidity, how deep the insects are in the soil, and soil temperature, among others. Differences in these parameters not controlled in both trials might also be responsible for differences in these results. It has been reported that soil insects are very difficult to control and results are sometimes not consistent among seasons due to still unknown reasons (Bueno et al. 2007).

In the second trial, endosulfan was not tested because of poor performance found in the first experiment (Figures 1A, 1B, and 1C), and seed treatment was included. Evaluating the results and observing that the insect population was composed mostly by nymphs at early stages, fipronil ( $37.5 \mathrm{~g}$ and 50 g. $100 \mathrm{~kg}$ of seeds $\left.^{-1}\right)$ and thiamethoxan $(70 \mathrm{~g} .100 \mathrm{~kg}$ of seeds $^{-1}$ ) were similar to furrow application (Figures 2A, $2 \mathrm{~B}$ and $2 \mathrm{C}$ ) and should be considered as promising chemical options to control L. fuscus outbreaks.

Furrow application of chlorpyrifos and fipronil, as well as fipronil and thiamethoxan applied as seed treatment can be effective alternatives to control $L$. fuscus outbreaks at cornfields in the conditions this study was conducted. 

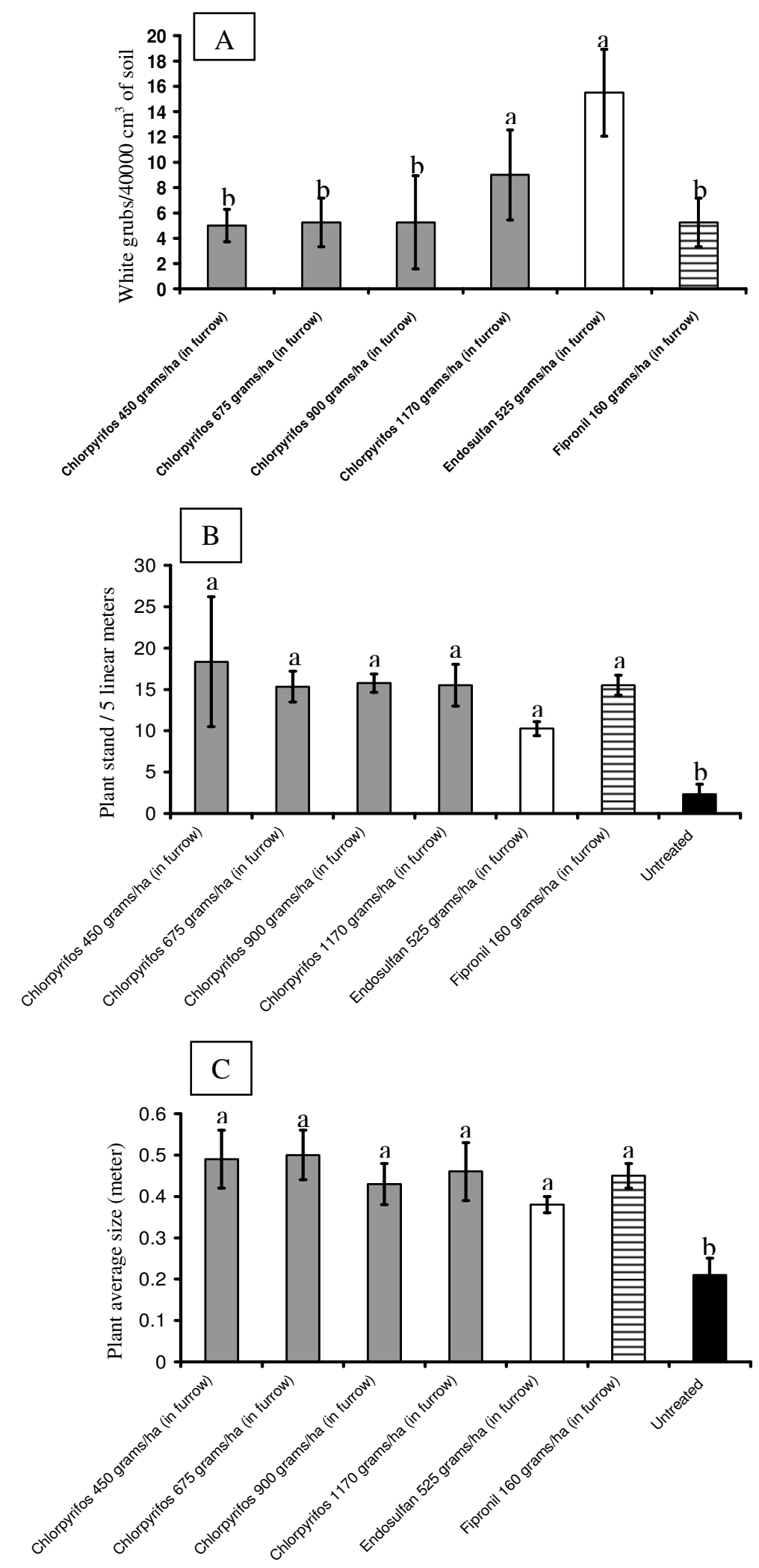

Figure 1. Results on Liogenys fuscus control at 45 days after sowing. (A) Mean \pm SE of $L$. fuscus nymphs / sample $\left(40000 \mathrm{~cm}^{3}\right)$. (B) Mean \pm SE of plants in 5 meter of row. (C) Mean \pm SE of plant size (m). Means followed by the same letter are statistically similar to each other accordingly to Tukey's test $(\alpha=0.05)$. Edéia, GO, 2004/2005. 


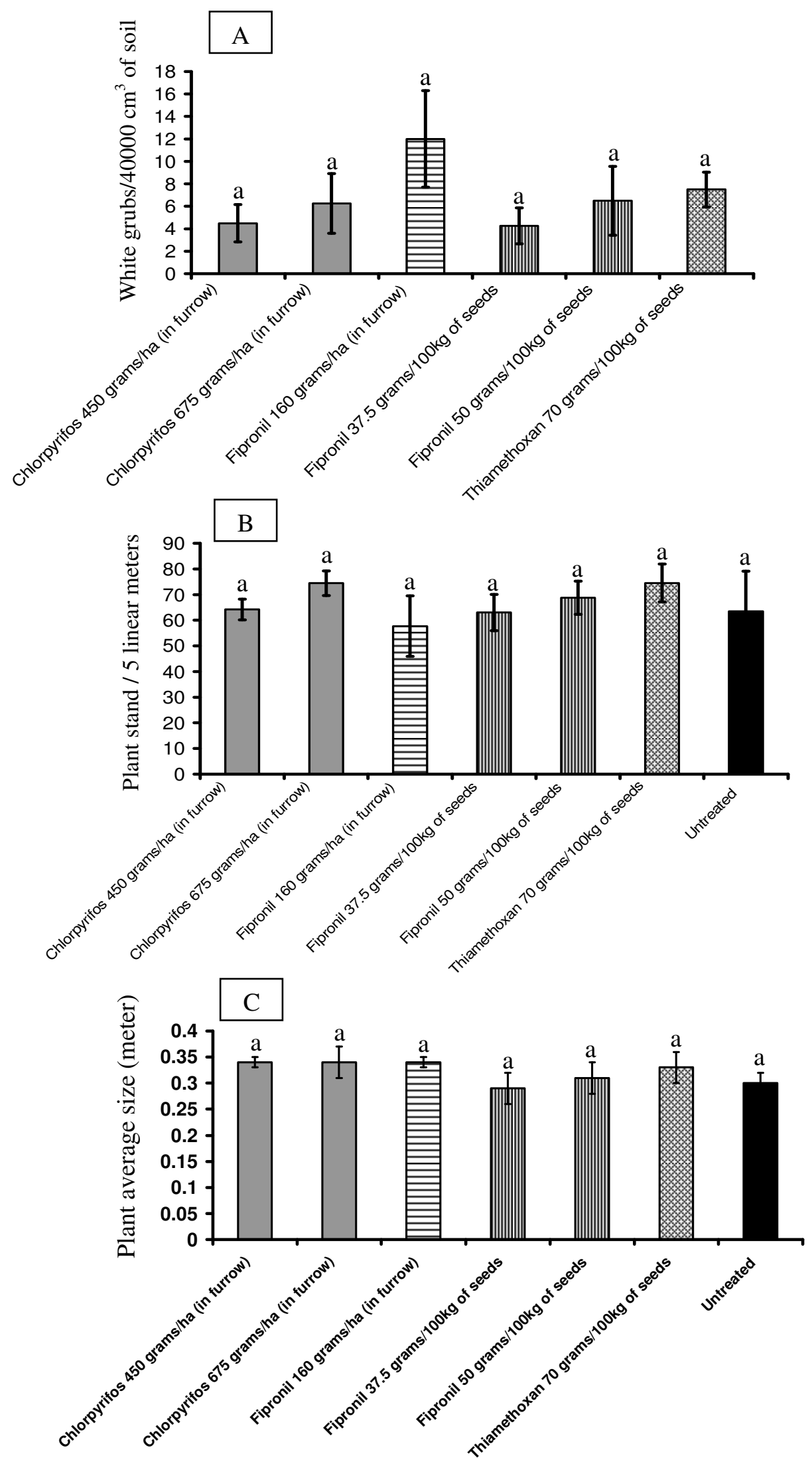

Figure 2. Results on Liogenys fuscus control at 26 days after planting. (A) Mean \pm SE of $L$. fuscus nymphs / sample $\left(40000 \mathrm{~cm}^{3}\right)$. (B) Mean \pm SE of plants in 5 meter of row. (C) Mean \pm SE of plant size (m). Means followed by the same letter are statistically similar to each other accordingly to Tukey's test $(\alpha=0.05)$. Edéia, GO, 2005/2006. 


\section{References Cited}

Bueno, A. F., J. Nunes Jr. \& L.J. Oliveira. 2007. Avaliação de inseticidas e enxofre no controle de percevejo castanho e de corós na cultura da soja, p. 45-47. In XXIX Reunião de Pesquisa de Soja da Região Central do Brasil, Campo Grande, MS, 225p.

Ceccon, G., A. Raga, A.P. Duarte \& R.C. Siloto. 2004. Efeito de inseticidas na semeadura sobre pragas iniciais e produtividade de milho safrinha em plantio direto. Bragantia, 63: 227-237.

Costa, R. B., P.M. Fernandes, M.A Morón, L.J Oliveira, E.A. Silva \& R.G. Barros. 2004. Bioecologia de corós no sistema de sucessão soja-milho safrinha, p. 47-48 In O.F. Saraiva (ed.). Resultados de pesquisa da EMBRAPA Soja-2003: Entomologia. Londrina (n. 245), 56p.

Cruz, I, P.A. Viana \& J.M. Waguil. 1999. Manejo das pragas iniciais de milho mediante o tratamento de sementes com inseticidas sistêmicos. Sete Lagoas (EMBRAPA-CNPMS, Circular Técnica, 31), 39p.

Grassen, D. N. 1993. Corós associados ao sistema plantio direto. p. 141-149. In EMBRAPA Centro Nacional de Pesquisa de Trigo (Passo Fundo, RS). Plantio direto no Brasil. Passo Fundo: Aldeia Norte/EMBRAPA-CNPT/FUNDACEP FECOTRIGO/Fundação ABC, 166p.

Mayo, Z. B. 1986. Field evaluation of insecticide for control of larvae of corn rootworms, p. 183-203. In J.L. Krysan \& T.A. Miller. (eds.). Methods for the study pest Diabrotica. New York: Springer-Verlag, 260p.

Morón, M. A. 2004. Insetos de Solo, p. 41-68. In J.R. Salvadori, C.J. Ávila \& M.T.B. Silva (eds), Pragas de Solo no Brasil. Passo Fundo, RS, 541p.
Oliveira, L. J. 1997. Ecologia comportamental e de interações com plantas hospedeiras em Phyllophaga cuyabana (Moser) (Coleoptera: Melolonthidae, Melolonthinae) e implicações para seu manejo na cultura da soja. Tese de doutorado, Instituto de Biologia, Universidade Estadual de Campinas (UNICAMP), Campinas, 148p.

Oliveira, L. J., B. Santos \& J.R.P. Parra. 2004. Corósda-soja, p. 167-190. In J.R. Salvadori, C.J. Ávila \& M.T.B. Silva (eds), Pragas de Solo no Brasil. Passo Fundo, RS, 541p.

Oliveira, L. J., B. Santos \& L.B. Amaral. 1992. Coró pequeno da Soja. Londrina: Embrapa Soja (Embrapa Soja documentos, 51). 4p.

Pedigo, L. P. 2002. Entomology and pest management. 4th edition. Pearson Education, Inc., Upper Saddle River, New Jersey. 742p.

Salvadori, J. R. 2000. Coró do trigo. (Embrapa Trigo, Documentos, 17) Passo Fundo: Embrapa Trigo. $56 \mathrm{p}$.

Silva, M. T. B. 1995. Aspectos biológicos e danos de Diloboderus abderus Sturm, 1826 (Coleoptera: Melolonthidae) em plantio direto. Dissertação de mestrado, Escola de Agronomia, Universidade Federal de Santa Maria, Santa Maria, RS, 76p.

Viana, P. A., I. Cruz, L.J Oliveira \& B.S. CorrêaFerreira. 2001. Manejo de pragas em agrossistema sob plantio direto, p. 63-72. In Informe agropecuário Plantio direto n. 22.

Waquil, J.M., C.J. Ávila, P.A. Viana, F.H. Valicente \& I. Cruz. 2004. Ocorrência e controle de pragas na cultura do milho no Mato Grosso do Sul Safrinha. Sete Lagoas (EMBRAPA-CNPMS, Circular Técnica, 46). 12 p. 